\title{
Geochemical comparison of mafic, felsic, and ultramafic rocks in the Hurricane Mountain mélange to the Boil Mountain ophiolite complex, west-central Maine
}

\author{
Harriet E. Van Vleck and Rachel J. Beane \\ Department of Geology, 6800 College Station, Bowdoin College, \\ Brunswick, ME 04011-8468 U.S.A.
}

Date Received: May 16, 2001

Date Accepted: September 6, 2001

\begin{abstract}
The Hurricane Mountain mélange, Maine, marks the suture zone between the suspected Boundary Mountain and Gander terranes. To the west the Hurricane Mountain mélange is bounded by the Boil Mountain ophiolite complex, and on the southeast it is overlain by the Dead River flysch. This ophiolite-mélange-flysch sequence may mark a terrane suture that trends northeast from the northern New Hampshire border across west-central Maine and into New Brunswick.

The matrix of the Hurricane Mountain mélange includes mafic volcanic, felsic volcanic, metasedimentary and serpentinite blocks. Major and trace element analysis of the igneous blocks in mélange shows strong geochemical similarities to mafic volcanic, felsic volcanic and ultramafic units of the Boil Mountain ophiolite complex. Analysis of relict clinopyroxene grains further supports a correlation between the mafic mélange blocks and the upper mafic unit of the Boil Mountain ophiolite complex. Overall, the field, petrographic, and geochemical data suggest that the Boil Mountain ophiolite complex is the probable source for the exotic blocks in the Hurricane Mountain mélange.
\end{abstract}

Le mélange du mont Hurricane, au Maine, marque la zone de suture entre les terranes présumés du mont Boundary et de Gander. À l'ouest, le mélange du mont Hurricane est limité par le cortège ophiolitique du mont Boil, et, à partir du sud-ouest, il est recouvert par le flysch de la rivière Dead. Ce cortège ophiolite-mélange-flysch pourrait marquer un terrane de suture orienté vers le nord-est à partir de la frontière septentrionale du New Hampshire et traversant le centre-ouest du Maine jusqu'à l'intérieur du Nouveau-Brunswick.

Les blocs à l'intérieur de la matrice du mélange du mont Hurricane comprennent des roches volcanomafiques, des roches volcanofelsiques, des blocs métasédimentaires et des serpentinites. Les analyses des éléments majeurs et des éléments traces des blocs du mélange révèlent des similarités géochimiques marquées avec les unités volcanomafiques, volcanofelsiques et ultramafiques du cortège ophiolithique du mont Boil. Une analyse de grains de clinopyroxène résiduels appuie elle aussi une corrélation entre les blocs du mélange mafique et l'unité mafique supérieure du cortège ophiolitique du mont Boil. En somme, les données de terrain et les données pétrographiques et géochimiques laissent supposer que le cortège ophiolitique du mont Boil constitue la source probable des blocs du mélange exotique du mont Hurricane.

Traduit par la rédaction

\section{INTRODUCTION}

The Hurricane Mountain mélange is seen in outcrop for approximately $160 \mathrm{~km}$ from the Thrasher peaks of northern New Hampshire to the northeastern edge of Moosehead Lake in central Maine. The mélange marks the suture zone of the Boundary Mountain and Gander terranes (Boone and Boudette 1989) (Fig. 1). The Hurricane Mountain mélange is the southeastern extent of the Boundary Mountain terrane, and the St. Daniel mélange in Québec marks the northwestern extent. To the west, the Hurricane Mountain mélange is bounded by the Boil Mountain ophiolite complex, and on the southeast it is overlain by the Dead River flysch (Boone and Boudette 1989). In the northern Appalachian orogen, sequences of ophiolite overlain successively by mélange and flysch formations are commonly interpreted as terrane suture zones. The Boil Mountain ophiolite, Hurricane Mountain mélange and Dead River flysch formations are an example of this accretionary pattern.

The Hurricane Mountain mélange comprises a variety of endogenous metasedimentary, and exotic volcanic and ultramafic blocks. Block emplacement previously has been ascribed to mechanisms of magmatic intrusion, faulting, and disruption of volcanic rocks, post or syn-Penobscottian deformation (Boone et al. 1989). In this paper, we test the hypothesis that mafic, felsic, and ultramafic blocks in the Hurricane Mountain mélange originated from the adjacent Boil Mountain ophiolite complex, and we propose a mechanism for block emplacement in the mélange.

\section{REGIONAL TECTONIC HISTORY}

Tectonic events in the northern Appalachian orogen were dominated by subduction towards the south/southeast (present-day coordinates). During the Penobscottian orogeny (Late Cambrian-Early Ordovician) the composite Boundary Mountain-Gander terrane was formed. The Hurricane Mountain mélange formed along the suture zone of these two terranes (Boone et al. 1989) (Fig. 2). This composite terrane 


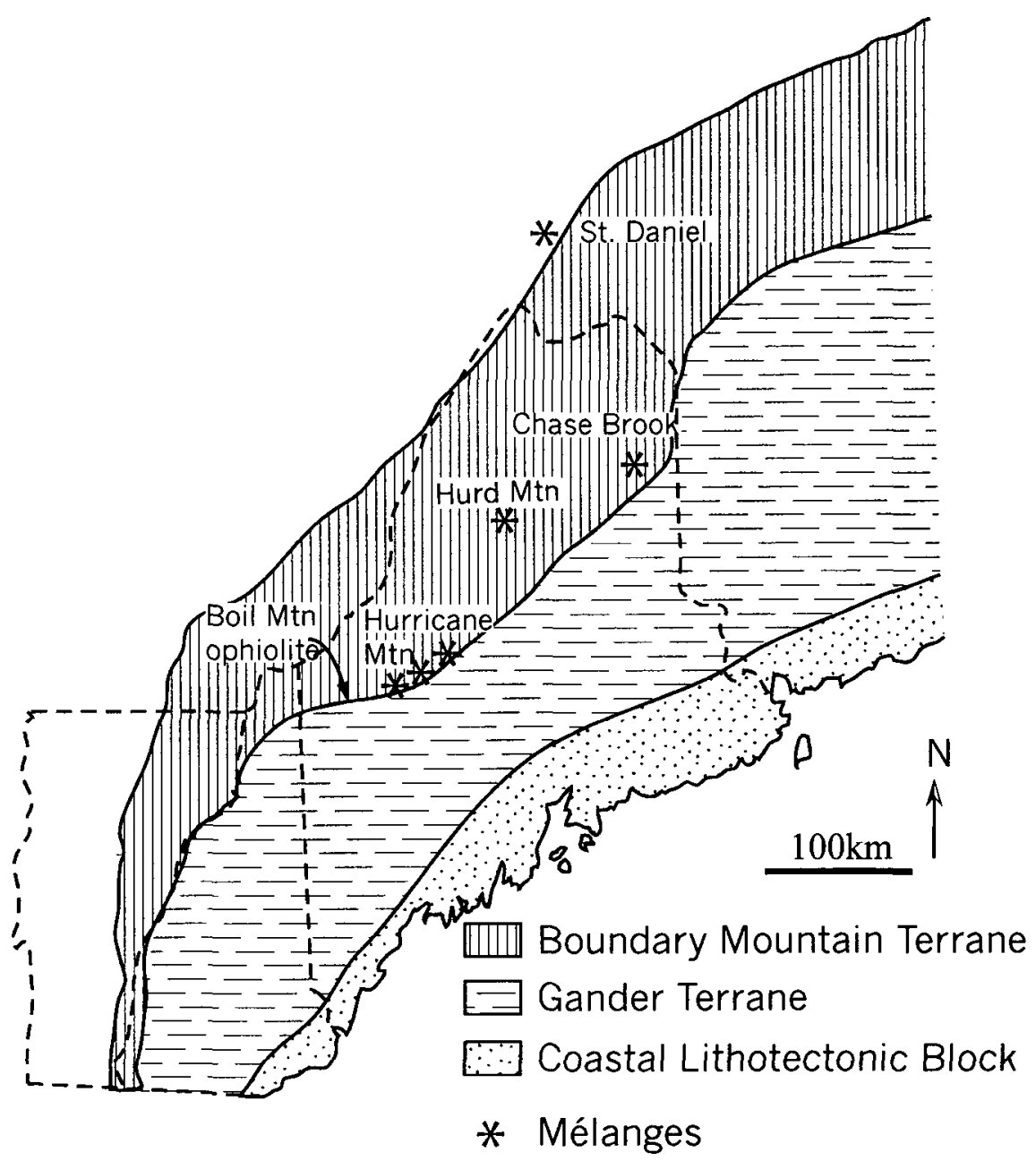

Fig. 1. Map of terrane boundaries and associated mélanges in the northern Appalachian orogen. Base map is adapted from Boone and Boudette (1989); mélange locations from Pollock (1989).

was then accreted onto the Laurentian craton during the Taconic Orogeny (middle Ordovician) (Boone and Boudette 1989). The continuation of the Boundary Mountain-Gander terrane boundary is the Dunnage-Gander terrane boundary that extends into Newfoundland where it continues to be distinguished by ophiolite complexes and mélanges (van Staal 1991).

Formation of the Hurricane Mountain mélange is constrained by stratigraphic and isotopic age data. Stratigraphic and field evidence demonstrates that the Hurricane Mountain mélange formed before the accretion of the joint Boundary Mountain-Gander terrane onto the Laurentian craton during the Taconic orogeny (middle Ordovician). Sparse paleontological data, and isotopic maximum and minimum dates indicate that the mélange formed primarily during the Late Cambrian-Early Ordovician period, roughly at the time of the Penobscottian orogeny (Boone and Boudette 1989). A maximum age of $540 \mathrm{Ma}$ is estimated from ${ }^{40} \mathrm{Ar} /{ }^{39} \mathrm{Ar}$ dating of hornblende from an exotic amphibolite block sampled near the northeastern end of the mélange (Boone et al. 1989). A minimum age of $485 \mathrm{Ma}$ for the mélange is based on ${ }^{40} \mathrm{Ar} /{ }^{39} \mathrm{Ar}$ dating of calcic amphibole grains from metagabbro clasts (Boone et al. 1989), However, a U-Pb zircon date of $500 \pm 10 \mathrm{Ma}$ for the felsic volcanic unit of the Boil Mountain ophiolite (Aleinikoff and Moench 1985) may limit the formation of the Hurricane Mountain mélange to between $500 \mathrm{Ma}$ and $540 \mathrm{Ma}$.

Structural deformation in the Hurricane Mountain mélange matrix is consistent with terrane accretion during the Penobscottian orogeny (Boone et al. 1989). Penobscottian deformation is dominant in this area, with light Acadian overprinting. Structural and geochemical evidence from our research indicates that the exotic blocks were in place before the onset of Acadian deformation.

\section{LOCAL GEOLOGICAL SETTING}

The Dead River and Hurricane Mountain formations, together with the Boil Mountain ophiolite complex, form a classic ophiolite-mélange-flysch sequence that reflects an ancient accretionary zone. Descriptions of these units are presented stratigraphically from the surface down, and from northeast to southwest; tectonically, this represents a cratonward progression. 


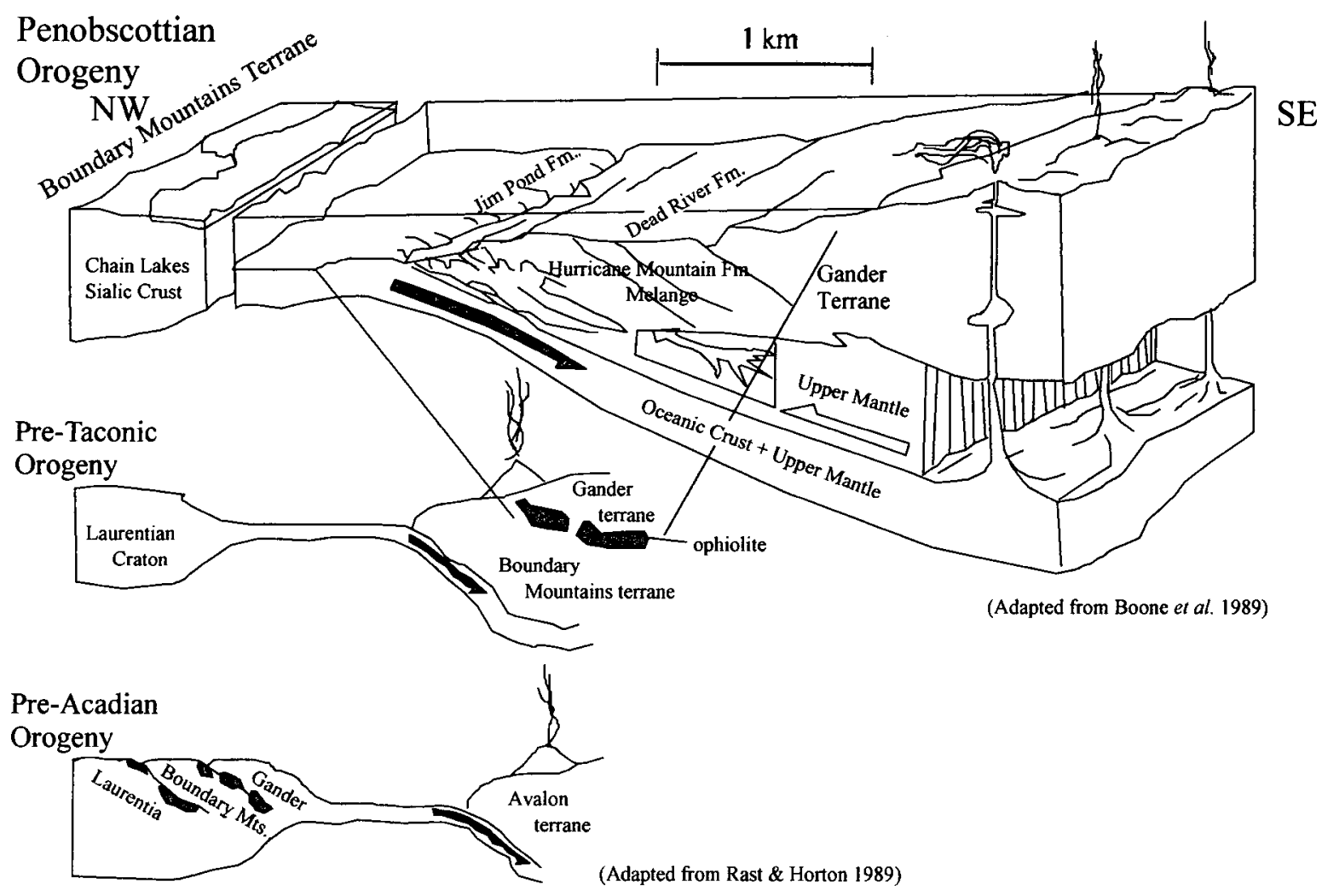

Fig. 2. Diagram of accretionary events in the northern Appalachian orogen (from Thomas 2000, adaptations from Boone et al. 1989, and Rast and Horton 1989).

\section{Dead River Formation}

The Dead River Formation is a flysch sequence (Boudette et al. 1985); the lower metapelite and upper metasandstone layers of the sequence are characterized by lamination varying from parallel to flasar bedding. Dead River sediments were deposited and repositioned by turbidity and bottom currents (Boudette et al. 1985). The Hurricane Mountain Formation commonly appears as lenses through this flysch carapace near Cold Stream and Indian Pond. The slate-phyllite of the Dead River Formation appears similar to the matrix of the Hurricane Mountain mélange, but is less highly fractured. The "lack of sulphides, lack of interbedded metasiltstones, and lack of extensive rusty weathering" serve to differentiate the darkgrey slate-phyllite of the Dead River Formation from the black-black slate of the Hurricane Mountain Formation (Burroughs 1979).

Equal proportions of the slate-phyllite and feldspathic chlorite-rich arenite characterize the Dead River Formation (Boone et al. 1989). Unlike the Hurricane Mountain Formation, Acadian deformation is clearly visible in the Dead River Formation overprinting earlier tectonic features. The flysch sequence appears to have been deposited by turbidity currents in a fore-arc environment (Boone et al. 1989). It overlies the Hurricane Mountain Formation.

\section{Hurricane Mountain Formation}

The Hurricane Mountain Formation is a mélange with a slate to phyllite matrix with rusty weathering. Regional metamorphism in this area reached prehnite-pumpellyite to lower greenschist facies conditions (Boone et al. 1989). One mafic volcanic breccia block, sampled in the northeastern part of the mélange yields evidence for lower epidote-amphibolite facies metamorphism prior to emplacement in the mélange. None of the other exotic blocks sampled has assemblages that indicate metamorphic conditions higher than greenschist facies. The Hurricane Mountain Formation is in fault contact with the Boil Mountain ophiolite complex.

\section{Boil Mountain ophiolite complex}

The Boil Mountain ophiolite complex will be defined here according to its use by Coish and Rogers (1987), such that it includes the upper three volcanic units of the Jim Pond Formation (Fig. 3). The sequence, from bottom up, includes ultramafic, gabbro, tonalite, mafic and felsic volcanic, and sedimentary units. The base ultramafic layer, pyroxenite to serpentinite in composition, overlies the Chain Lakes massif (Fig. 2).

Above the ultramafic layer, the metamorphosed gabbro layer contains clinopyroxene, actinolite, and plagioclase. The composition of the layer varies between gabbro and diorite, and textures range from cumulate to subophitic.

The tonalite unit, between the gabbro and volcanic rocks, has strained quartz and myrmekitic feldspars. Coish and Rogers (1987) argued that this unit may be a later intrusion.

The mafic volcanic units primarily occur as pillowed or massive flows. Minerals in the greenschist-facies, mafic units 


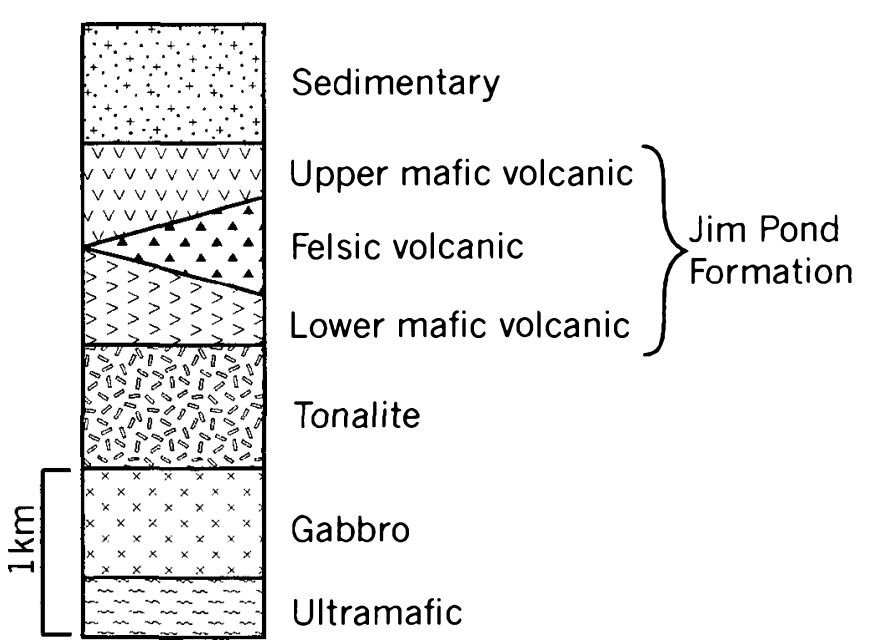

Fig. 3. Stratigraphic column of the Boil Mountain ophiolite complex (drawn after Coish and Rogers 1987).

include: albite, actinolite, chlorite, calcite, epidote, and quartz. The mafic volcanic units are divided into an upper mafic unit and a lower mafic unit, separated by a felsic volcanic unit. Grain size is coarser and clinopyroxene phenocrysts are more abundant in the upper mafic unit than in the lower mafic unit. The plagioclase-chlorite-actinolite intergranular matrix in the lower mafic unit contains no relict clinopyroxene phenocrysts (Coish and Rogers 1987).

The felsic volcanic unit, which separates the two mafic volcanic units, includes "metamorphosed dacite, quartz-latite flows and related ash-flow deposits, breccia, and epiclastic rocks" (Boudette 1982). The felsic unit is linked by trace element analysis to the lower mafic unit (Coish and Rogers 1987). Textural analysis, because of later recrystallisation, does not prove definitively whether the felsic unit was formed by lava flows or as pyroclastic deposits (Coish and Rogers 1987).

\section{FIELD DESCRIPTIONS}

The Hurricane Mountain mélange follows the regional northeast-southwest structural trend. The primary foliation in the matrix parallels this trend, striking roughly NE throughout the mélange with a near-vertical dip. Areas where the Hurricane Mountain matrix foliation is strongest seem to correspond to sections with fewer exotic blocks. Near the northeastern extent of the mélange, the matrix appears slightly more massive. Throughout the mélange the matrix is polydeformed, recording evidence of the Penobscottian and Acadian orogenies.

Mafic, ultramafic, and felsic volcanic blocks average 2-4 $\mathrm{m}$ wide and 3-5 $\mathrm{m}$ high. Many blocks are oblong with tops leaning variably to the southeast. Blocks commonly appear in small clusters of their lithologic type, suggesting they may have fragmented from larger blocks or stratigraphic units. More mafic blocks occur in the mélange than ultramafic or felsic volcanic blocks. Other block lithologies present within the mélange include metapelite and feldspathic wacke and arenite (Boone et al. 1989).

\section{Petrography}

Petrographic analysis of the Hurricane Mountain blocks showed a range of compositions and textures (Table 1). A typical mineral assemblage for mafic samples includes augite, albite, chlorite, epidote, biotite, and ilmenite-spinel. Felsic volcanic samples include rounded quartz-rich clasts, within fine-grained flow textures. Ultramafic blocks are primarily serpentinite, with sheets of exuded quartz (slickensides), and inclusions of magnesite, chromite, magnetite, titanite, pyrite and biotite. Compared to the Hurricane Mountain blocks, the ultramafic samples we collected from the Boil Mountain ophiolite complex are less serpentinized and retain some relict clinopyroxene grains.

Table 1. Mineral assemblages for Hurricane Mountain samples, and two samples from Boil Mountain ophiolite complex.

\begin{tabular}{lcccccccccc}
\hline & \multicolumn{3}{c}{ Mafic } & \multicolumn{3}{c}{ Felsic } & & \multicolumn{2}{c}{ Ultramafic } & \multicolumn{2}{c}{ Boil Mtn. Oph. } \\
& 114 & 158 & 163 & 116 & 147 & 162 & 122 & 159 & 145 & 153 \\
\hline Augite & $\times$ & $\times$ & $\times$ & & & & & & $\times$ & $\times$ \\
Serpentine & & & & & & & $\times$ & $\times$ & & \\
Actinolite & $\times$ & & $\times$ & & & & & & & \\
K-feldspar & & & & $\times$ & $\times$ & $\times$ & & & & \\
Plagioclase & $\times$ & $\times$ & $\times$ & & & & & & & \\
Chlorite & $\times$ & $\times$ & $\times$ & $\times$ & $\times$ & $\times$ & & & $\times$ & $\times$ \\
Epidote & $\times$ & $\times$ & $\times$ & $\times$ & $\times$ & & & & $\times$ & $\times$ \\
Pyrite & & & & & & & $\times$ & $\times$ & & $\times$ \\
Quartz & & & & $\times$ & $\times$ & $\times$ & & & & \\
Biotite & $\times$ & & $\times$ & & $\times$ & & $\times$ & $\times$ & & \\
Muscovite & & & & $\times$ & $\times$ & $\times$ & & & & \\
Titanite & & & & & & & & & $\times$ & \\
Il-Spinel group & & $\times$ & & & & & $\times$ & $\times$ & & \\
\hline
\end{tabular}


Table 2. Major and trace element data for blocks from the Hurricane Moutain melange and two samples from Boil Mountain ophiolite complex.

\begin{tabular}{|c|c|c|c|c|c|c|c|c|c|c|}
\hline & \multicolumn{3}{|c|}{ Mafic } & \multicolumn{3}{|c|}{ Felsic } & \multicolumn{2}{|c|}{ Ultramafic } & \multicolumn{2}{|c|}{ Boil Mtn. Oph. } \\
\hline & 114 & 158 & 163 & 116 & 147 & 162 & 122 & 159 & 145 & 153 \\
\hline $\mathrm{SiO}_{2}$ & 48.23 & 48.17 & 48.99 & 75.49 & 78.84 & 64.14 & 42.07 & 41.57 & 51.74 & 44.07 \\
\hline $\mathrm{TiO}_{2}$ & 1.62 & 1.76 & 1.98 & 0.82 & 0.08 & 0.69 & 0.04 & 0.01 & 0.70 & 0.83 \\
\hline $\mathrm{Al}_{2} \mathrm{O}_{3}$ & 14.45 & 15.29 & 13.61 & 12.84 & 11.75 & 14.71 & 1.01 & 0.94 & 14.99 & 16.02 \\
\hline $\mathrm{Cr}_{2} \mathrm{O}_{3}$ & 0.04 & 0.03 & 0.01 & 0.01 & 0.00 & 0.01 & 0.25 & 0.32 & 0.03 & 0.01 \\
\hline $\mathrm{Fe}_{2} \mathrm{O}_{3}$ & 11.27 & 12.35 & 14.23 & 3.55 & 1.42 & 6.01 & 7.52 & 7.63 & 9.80 & 15.05 \\
\hline $\mathrm{MnO}$ & 0.20 & 0.25 & 0.25 & 0.03 & 0.03 & 0.07 & 0.04 & 0.08 & 0.10 & 0.23 \\
\hline $\mathrm{MgO}$ & 7.40 & 6.85 & 6.43 & 0.77 & 0.80 & 3.98 & 35.17 & 35.00 & 8.33 & 7.39 \\
\hline $\mathrm{CaO}$ & 11.43 & 9.17 & 8.83 & 0.27 & 0.20 & 2.37 & 0.06 & 0.93 & 3.96 & 12.22 \\
\hline $\mathrm{Na}_{2} \mathrm{O}$ & 1.61 & 3.18 & 2.70 & 0.44 & 0.72 & 2.47 & 0.06 & 0.02 & 5.51 & 0.37 \\
\hline $\mathrm{K}_{2} \mathrm{O}$ & 0.87 & 0.80 & 0.58 & 3.02 & 3.81 & 2.32 & $<0.04$ & $<0.04$ & 0.61 & 0.19 \\
\hline $\mathrm{P}_{2} \mathrm{O}_{5}$ & 0.20 & 0.14 & 0.15 & 0.18 & 0.03 & 0.09 & 0.06 & 0.09 & 0.10 & 0.08 \\
\hline Total & 97.32 & 97.99 & 97.76 & 97.42 & 97.68 & 96.86 & 86.28 & 86.59 & 95.87 & 96.46 \\
\hline \multicolumn{11}{|c|}{ Trace elements (ppm) } \\
\hline $\mathrm{Ba}$ & 85 & 630 & $<5$ & 84 & 693 & 17 & 201 & 88 & $<5$ & 497 \\
\hline $\mathrm{Ni}$ & 54 & 21 & 54 & 52 & 2 & 17 & 30 & 51 & 1442 & 78 \\
\hline $\mathrm{Rb}$ & 42 & 102 & 2 & 5 & 124 & 4 & 17 & 16 & 1 & 73 \\
\hline $\mathrm{Sr}$ & 278 & 51 & 4 & 74 & 14 & 119 & 174 & 150 & 5 & 164 \\
\hline $\mathrm{Y}$ & 33 & 27 & 1 & 15 & 20 & 8 & 36 & 36 & 0 & 24 \\
\hline $\mathrm{Zr}$ & 96 & 405 & 3 & 25 & 49 & 6 & 95 & 96 & 2 & 118 \\
\hline
\end{tabular}

\section{BULK ROCK CHEMISTRY}

Bulk rock major and trace element chemistry is used to test the hypothesis that blocks of the Hurricane Mountain mélange originated from the Boil Mountain ophiolite complex. Bulk rock analyses by ICP-MS were done by Acme Labs in Toronto, Canada. Hurricane Mountain mélange samples are classified based on petrographic observations and geochemical classification (Table 2, Fig. 4): 114, 158, and 163 are mafic volcanic rocks; 116,147 , and 162 are felsic volcanic rocks; and 122 and 159 are serpentinite. Boil Mountain ophiolite samples are 145, a pillow basalt, and 153, a clinopyroxene-rich breccia. New data presented in this paper are supplemented by geochemical data for the Boil Mountain ophiolite complex presented by Coish and Rogers (1987).

\section{Major elements}

Mafic samples from the Hurricane Mountain mélange are compared to the upper mafic, lower mafic, and gabbro units of the Boil Mountain ophiolite complex (Fig. 5a-i). Samples range between 45 and $50 \% \mathrm{SiO}_{2}$, and a strong similarity is apparent in the abundances of $\mathrm{Al}_{2} \mathrm{O}_{3}, \mathrm{FeO}, \mathrm{MgO}$, and $\mathrm{K}_{2} \mathrm{O}$ in the Hurricane Mountain samples and those of the upper mafic unit of the Boil Mountain ophiolite complex (Fig. 5a, b, c, and f). The Hurricane Mountain samples share more similarities with the upper mafic unit of the Boil Mountain ophiolite complex than with either the lower mafic or gabbro units. The high abundance of $\mathrm{Ti}$ in Hurricane Mountain mafic rocks distinguishes it from the lower mafic and gabbro units of the Boil Mountain ophiolite complex (Fig. 5g).
Felsic volcanic samples from the Hurricane Mountain mélange show good correlation with the fields drawn for the Boil Mountain felsic volcanic unit (after Coish and Rogers 1987) (Fig. 5). Felsic sample 162 is low in Si compared to the range from Coish and Rogers (1987) and plots closer to the field of the Boil Mountain tonalite unit for most major elements.

The two Hurricane Mountain serpentinite samples have lower abundances of all major elements, except $\mathrm{Mg}$, compared

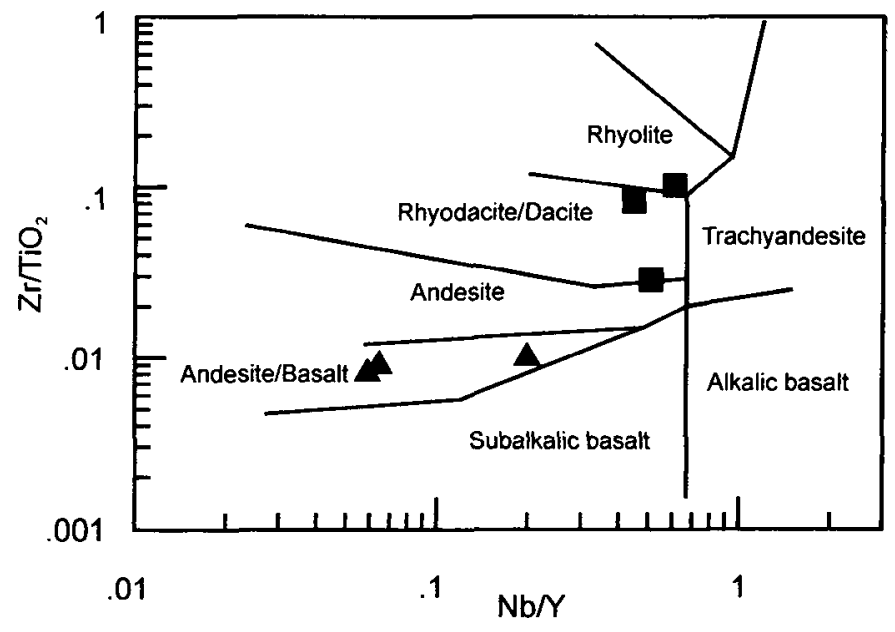

Fig. 4. Classification diagram indicating igneous protoliths and distinguishing the mafic (triangles) and felsic (squares) blocks from the Hurricane Mountain melange (fields from Pearce and Cann 1973). 

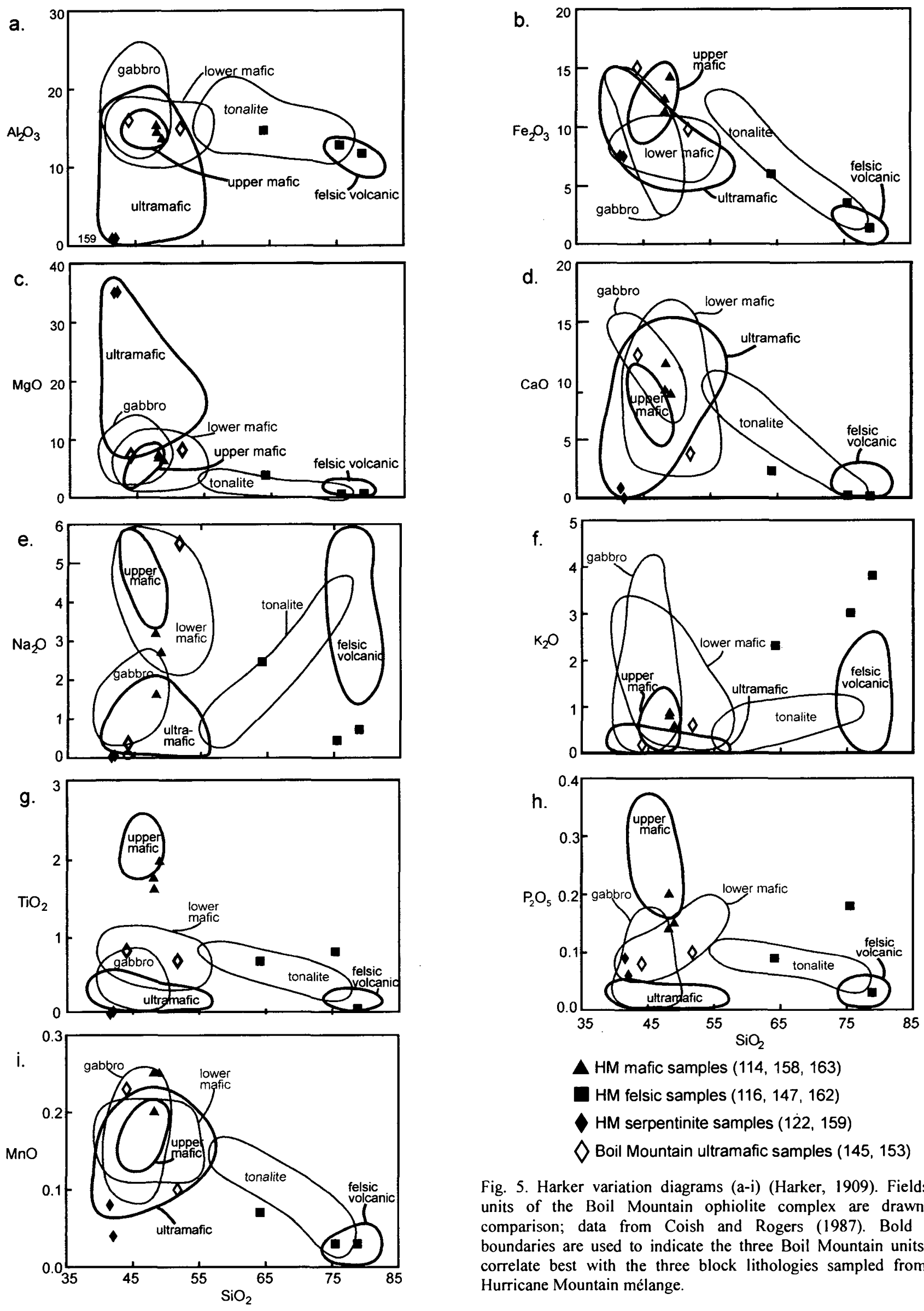

Fig. 5. Harker variation diagrams (a-i) (Harker, 1909). Fields for units of the Boil Mountain ophiolite complex are drawn for comparison; data from Coish and Rogers (1987). Bold field boundaries are used to indicate the three Boil Mountain units that correlate best with the three block lithologies sampled from the Hurricane Mountain mélange. 
with the two Boil Mountain ultramafic samples that we collected. These two Boil Mountain ultramafic samples plot at the upper unit of the ultramafic field of Coish and Rogers (1987).

The $\mathrm{MgO}-\mathrm{Fe}_{2} \mathrm{O}_{3}$ and $\mathrm{P}_{2} \mathrm{O}_{5}-\mathrm{TiO}_{2}$ plots test similarities observed on the Harker diagrams between the Hurricane Mountain samples and the Boil Mountain ophiolite complex (Fig. 6). The plots show strong similarities the Hurricane Mountain mafic samples and the Boil Mountain upper mafic unit, and the felsic samples plot within or adjacent to the felsic volcanic fields of the Boil Mountain ophiolite complex (Fig. $6 a$ and $b$ ). The Hurricane Mountain serpentinite samples plot in the high-Mg portion of the Boil Mountain ultramafic field, most likely due to the greater degree of serpentinization observed in the Hurricane Mountain samples compared to the Boil Mountain ophiolite samples.

\section{Trace elements}

Trace and rare earth element plots are used to further compare the Hurricane Mountain mafic blocks and the Boil Mountain lower mafic, gabbro, and upper mafic units. The Hurricane Mountain mafic blocks are enriched in HFSE, and generally in REE, compared to the lower mafic unit (Table 3, Fig. 7a and $b$ ), and they differ significantly from the gabbro unit (Fig. 7c and d). The trace element abundance, the slight convex shape of the curve, and the small negative Eu anomaly of the Hurricane Mountain mafic samples closely match the Boil Mountain upper mafic unit (Fig. 7c and d). Coish and Rogers (1987) noted that the REE pattern of the Boil Mountain upper mafic unit is similar to that of the island-arcderived Smartville ophiolite (Menzies et al. 1980).

These trace and rare earth element data suggest that the mafic samples of the Hurricane Mountain mélange may have originated from the upper mafic unit of the Boil Mountain ophiolite complex. This relation is further supported by Fig. 8, where the Hurricane Mountain mafic samples distinctly plot near the upper mafic field, separate from the lower mafic field.

The Hurricane Mountain and Boil Mountain felsic samples show a large range in abundance of REE and trace elements compared to the tighter patterns of the mafic volcanic rocks. The extended range may indicate fractionation of the magma, or differences between successive eruptions. Felsic volcanic block samples of the Hurricane Mountain mélange are enriched in LILE and LREE relative to the felsic samples of the Boil Mountain sequence (Fig. 7e and $\mathrm{f}$ ). With respect to HFSE, Hurricane samples are not consistently more or less abundant than the Boil Mountain samples, although Hurricane Mountain samples are depleted in HREE (Fig. 7e). The REE patterns for both the Hurricane Mountain and the Boil Mountain felsic samples show negative Eu anomalies and negative slopes.

A negative $\mathrm{Nb}$ anomaly as compared with $\mathrm{K}$ and $\mathrm{La}$ values is interpreted as an indication of arc magmas (Kelemen et al. 1993). Felsic samples from the Hurricane Mountain mélange show strong $\mathrm{Nb}$ negative anomalies relative to $\mathrm{K}$ and $\mathrm{La}$, and mafic samples show moderate negative anomalies (Fig. $7 \mathrm{~g}$ ). This characteristic suggests that the source of the
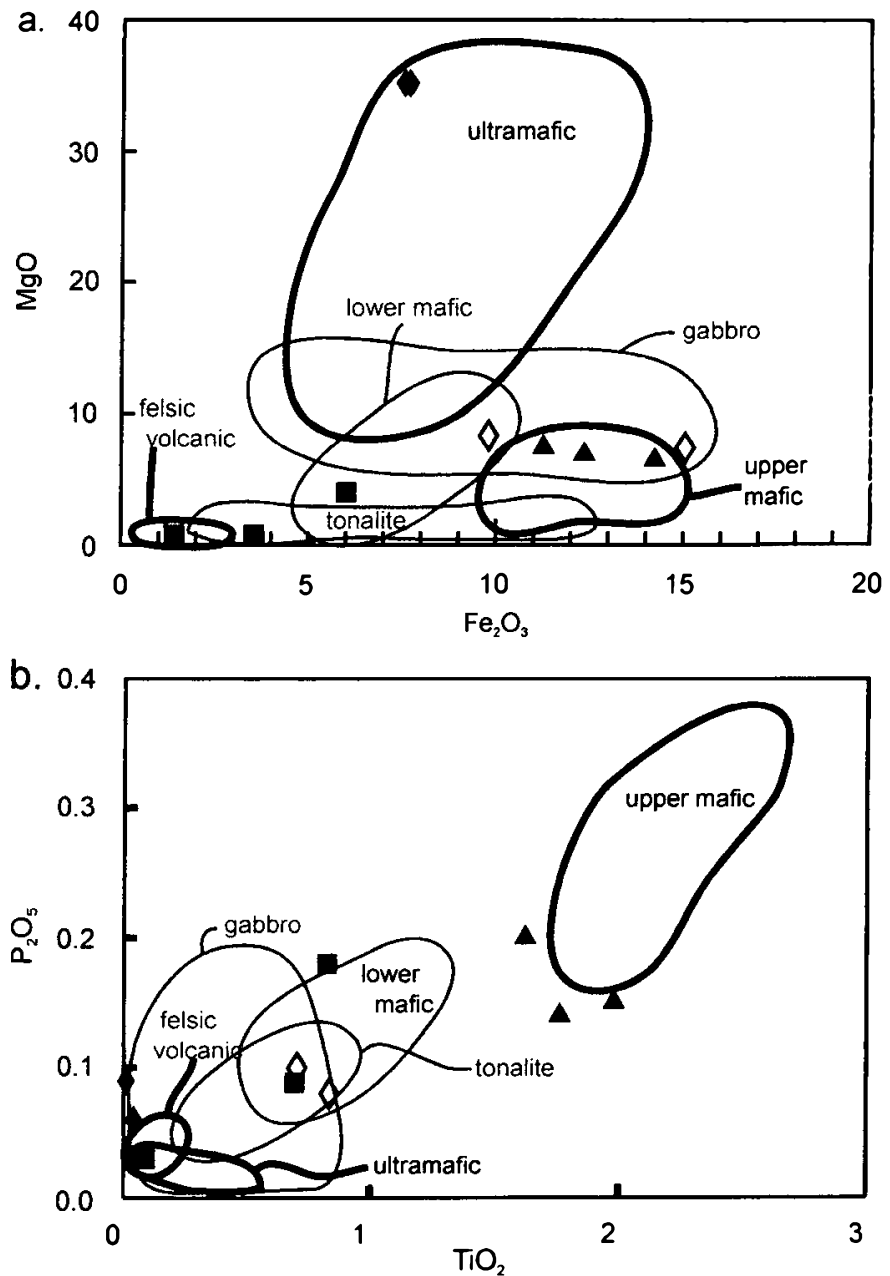

Fig. 6. Plots of (a) $\mathrm{Fe}_{2} \mathrm{O}_{3}-\mathrm{MgO}$ and (b) $\mathrm{TiO}_{2}-\mathrm{P}_{2} \mathrm{O}_{5}$ compare samples from the Hurricane Mountain mélange with fields for the Boil Mountain ophiolite units. Symbols are as in Fig. 5.

Hurricane Mountain felsic and mafic blocks formed in an arc setting.

\section{Classification diagrams}

Acknowledging that the alkali vs. $\mathrm{SiO}_{2}$ classification diagram (Fig. 9) is most accurate for unmetamorphosed volcanic rocks, without alkali mobilization from weathering and metamorphism (Wilson 1989), we have chosen to include this graph as an approximate comparison of protoliths for the Hurricane Mountain mélange and Boil Mountain ophiolite samples. Based on this diagram, the mafic mélange blocks had a basaltic protolith and the felsic mélange blocks had a rhyolite-dacite protolith. Samples from the Boil Mountain gabbro and upper mafic unit plot in the basaltic fields, and samples from the lower mafic unit plot in the basalt to basaltandesite fields. The felsic volcanic samples from the Boil Mountain ophiolite plot as rhyolite.

The major element tectonic diagram (Fig. 10a) shows a stronger correlation between the Hurricane Mountain mafic blocks and the Boil Mountain upper mafic unit than with the lower mafic unit. Tectonic classification diagrams suggest that the Hurricane Mountain mafic and Boil Mountain upper mafic units were formed in an oceanic, not orogenic, environment 
Table 3. Trace and rare earth element abundances (ppm) in Hurricane Mountain samples and two samples from Boil Mountain ophiolite complex.

\begin{tabular}{|c|c|c|c|c|c|c|c|c|c|c|}
\hline & \multicolumn{3}{|c|}{ Mafic } & \multicolumn{3}{|c|}{ Felsic } & \multicolumn{2}{|c|}{ Ultramafic } & \multicolumn{2}{|c|}{$\mathrm{BMO}^{*}$} \\
\hline & 114 & 158 & 163 & 116 & 147 & 162 & 122 & 159 & 145 & 153 \\
\hline Sc & 39 & 8 & 7 & 38 & 8 & 59 & 44 & 42 & 8 & 14 \\
\hline Mo & 1 & 1 & $<1$ & $<1$ & 1 & $<1$ & $<1$ & $<1$ & $<1$ & 9 \\
\hline $\mathrm{Cu}$ & 84 & 9 & 4 & 76 & 3 & 94 & 4 & 55 & 3 & 84 \\
\hline $\mathrm{Pb}$ & $<3$ & 5 & $<3$ & $<3$ & 24 & $<3$ & $<3$ & $<3$ & $<3$ & 8 \\
\hline $\mathrm{Zn}$ & 49 & 39 & 5 & 59 & 16 & 58 & 51 & 72 & 21 & 65 \\
\hline As & $<2$ & 9 & 4 & 3 & $<2$ & $<2$ & $<2$ & $<2$ & $<2$ & 3 \\
\hline $\mathrm{Cd}$ & $<0.2$ & $<0.2$ & 0.2 & $<0.2$ & $<0.2$ & $<0.2$ & $<0.2$ & $<0.2$ & $<0.2$ & $<0.2$ \\
\hline $\mathrm{Sb}$ & 0.9 & $<0.5$ & $<0.5$ & $<0.5$ & $<0.5$ & $<0.5$ & $<0.5$ & $<0.5$ & $<0.5$ & $<0.5$ \\
\hline $\mathrm{Bi}$ & $<0.5$ & $<0.5$ & $<0.5$ & $<0.5$ & $<0.5$ & $<0.5$ & $<0.5$ & $<0.5$ & $<0.5$ & 0.7 \\
\hline Co & 42.6 & 4.7 & 96.4 & 28.8 & 1.1 & 51.3 & 35.9 & 39.3 & 90.2 & 17.7 \\
\hline Cs & 1.9 & 2.3 & 0.8 & 0.4 & 2.1 & 0.1 & 0.3 & 0.4 & 1.2 & 1.8 \\
\hline $\mathrm{Ga}$ & 18.8 & 14.7 & 1.5 & 14 & 15 & 18.1 & 19.8 & 17.9 & 1.3 & 23.8 \\
\hline Hf & 3.1 & 11.4 & $<0.5$ & 0.9 & 2.3 & $<0.5$ & 3.1 & 2.9 & $<0.5$ & 3.6 \\
\hline $\mathrm{Nb}$ & 6.6 & 12 & $<0.5$ & 0.6 & 12 & $<0.5$ & 2.3 & 2.2 & $<0.5$ & 12.1 \\
\hline Sn & 2 & 3 & 1 & 3 & 6 & 3 & 3 & $<1$ & $<1$ & 1 \\
\hline $\mathrm{Ta}$ & 0.5 & 0.9 & $<0.1$ & $<0.1$ & 0.9 & $<0.1$ & $<0.1$ & $<0.1$ & $<0.1$ & 1 \\
\hline Th & 0.4 & 10.5 & $<0.1$ & 0.4 & 7.1 & 0.1 & 0.2 & 0.5 & $<0.1$ & 13.3 \\
\hline $\mathrm{Tl}$ & $<0.1$ & 0.1 & $<0.1$ & $<0.1$ & 0.2 & 0.1 & $<0.1$ & 0.1 & 0.5 & 0.6 \\
\hline $\mathrm{U}$ & 0.3 & 2.2 & $<0.1$ & 0.2 & 2.1 & 0.1 & 0.1 & 0.3 & $<0.1$ & 11 \\
\hline V & 295 & 48 & 28 & 236 & $<5$ & 592 & 342 & 355 & 34 & 257 \\
\hline W & 1 & 5 & $<1$ & $<1$ & 6 & 1 & $<1$ & $<1$ & $<1$ & 3 \\
\hline La & 7 & 32.8 & $<0.5$ & 3.3 & 15.3 & 0.7 & 5.2 & 6.2 & $<0.5$ & 39.2 \\
\hline $\mathrm{Ce}$ & 17.1 & 66.5 & 1.2 & 7.9 & 34.4 & 1.8 & 14.2 & 15.6 & $<0.5$ & 70.6 \\
\hline $\operatorname{Pr}$ & 2.64 & 7.62 & 0.14 & 1.12 & 4.13 & 0.31 & 2.41 & 2.61 & 0.07 & 8.17 \\
\hline Nd & 12.8 & 29.9 & $<0.4$ & 6.5 & 15.4 & 1.8 & 11.9 & 13 & $<0.4$ & 30.1 \\
\hline $\mathrm{Sm}$ & 4.2 & 5.7 & $<0.1$ & 1.7 & 4 & 0.7 & 4 & 4 & $<0.1$ & 5.7 \\
\hline $\mathrm{Eu}$ & 1.37 & 1.07 & 0.13 & 0.6 & 0.65 & 0.42 & 1.31 & 1.33 & $<0.05$ & 1.24 \\
\hline Gd & 4.63 & 5.2 & 0.11 & 2.34 & 3.27 & 1.15 & 5.33 & 5.4 & 0.06 & 4.68 \\
\hline $\mathrm{Tb}$ & 0.88 & 0.8 & 0.01 & 0.39 & 0.55 & 0.27 & 0.92 & 0.94 & 0.01 & 0.71 \\
\hline Dy & 5.79 & 4.67 & 0.09 & 2.69 & 3.69 & 1.62 & 6.49 & 6.29 & 0.06 & 4.11 \\
\hline Ho & 1.19 & 0.96 & $<0.05$ & 0.57 & 0.78 & 0.37 & 1.29 & 1.38 & $<0.05$ & 0.89 \\
\hline $\mathrm{Er}$ & 3.82 & 2.85 & 0.06 & 1.8 & 2.42 & 1.03 & 4 & 4.02 & 0.06 & 2.52 \\
\hline $\mathrm{Tm}$ & 0.52 & 0.4 & $<0.05$ & 0.27 & 0.37 & 0.15 & 0.58 & 0.57 & $<0.05$ & 0.42 \\
\hline $\mathrm{Yb}$ & 3.45 & 2.5 & 0.06 & 1.81 & 2.39 & 0.95 & 3.84 & 3.82 & 0.07 & 2.56 \\
\hline $\mathrm{Lu}$ & 0.47 & 0.38 & $<0.01$ & 0.27 & 0.33 & 0.13 & 0.53 & 0.52 & $<0.01$ & 0.38 \\
\hline
\end{tabular}

* $\mathrm{BMO}=$ Boil Mountain ophiolite complex samples

(Fig. 10). This classification, combined with the negative $\mathrm{Nb}$ anomaly, leads us to suggest that the source of the felsic and mafic blocks formed in an island-arc or arc basin environment. In their paper, Coish and Rogers (1987) suggested that the upper mafic unit formed in a well-established marginal basin, and the lower mafic unit and felsic volcanic rocks formed in an island-arc setting or developing marginal basin.

\section{MINERAL CHEMISTRY}

Clinopyroxene analyses by SEM-EDS (at Bowdoin College) for mafic samples 114, 158, and 163 (Table 4) show the pyroxene grains to be augite in composition (Fig. 11). Clinopyroxene from samples 114 and 163 plot in the calcalkaline field, while those from sample 158 plot in the tholeiitic field (Fig. 12a). Augite analyses from samples 114 and 163 plot within the fields of augite data for the Boil Mountain upper mafic unit (Fig. 12b and c) from Coish and Rogers (1987). The hypothesis that both the Hurricane Mountain mafic blocks and the Boil Mountain upper mafic volcanic unit formed in non-orogenic environments is supported by results of clinopyroxene analysis (Fig. 12b, fields after Leterrier (1982)).

\section{SUMMARY}

1.Mafic and felsic volcanic blocks and serpentinite blocks from the Hurricane Mountain mélange have strong petrographic and geochemical similarities to the upper mafic volcanic, felsic volcanic, and ultramafic units of the neighbouring Boil Mountain ophiolite complex. The similarities suggest the Boil Mountain ophiolite complex was the source of these blocks in the Hurricane Mountain mélange. 2. Deformation fabrics in the blocks indicate they were embedded within the mélange prior to the Devonian Acadian orogeny.

3. Blocks analyzed were metamorphosed at lower greenschist facies.

4. Geochemical analysis of the blocks suggests formation in a marginal, possibly fore-arc, basin, during the Penobscottian accretion of the Gander terrane onto the Boundary Mountain terrane.

\section{Discussion}

The geochemical data presented in this paper suggest the Boil Mountain ophiolite complex is the probable source of the mafic volcanic block lithologies sampled from the Hurricane Mountain mélange. Furthermore, the ophiolite sequence is likely also to be the source of the felsic volcanic and serpentinite blocks. The geochemistry of the exotic melange blocks, including the negative $\mathrm{Nb}$ anomaly, suggests that the source of the blocks originated in a fore-arc/marginal basin environment. This result is consistent with previous interpretations that the Boil Mountain ophiolite complex formed in a marginal basin (Coish and Rogers 1987). Overlying the Hurricane Mountain mélange, the Dead River flysch is interpreted to have accumulated in a fore-arc basin or slope (Boone and Boudette 1989; Boone et al. 1989). With the Boil Mountain ophiolite complex to the west forming in a marginal basin, and the Dead River Formation to the east being deposited in a fore-arc basin or slope, it may be reasonable to interpret that the Hurricane Mountain mélange formed in the accretionary wedge of a subduction zone.

Mafic, felsic, and ultramafic blocks may have fragmented from the Boil Mountain ophiolite complex during subductionrelated faulting. These faulted blocks may have been brought to the forming Hurricane Mountain mélange through gravitydriven submarine slides, as proposed by Boudette et al. (1985). Continued subduction then sandwiched the Hurricane Mountain mélange between the Boundary Mountain terrane and the accreting Gander terrane, during the Penobscottian orogeny.

It is interesting to note that several mélanges in the northern Appalachian orogen form a curvilinear trend (c.f. Fig. 1). Across Maine, the Hurricane Mountain, Chase Brook and Hurd Mountain mélanges were compared by Pollock (1989). In so doing, Pollock (1989) was able to extend the suture zone of the Boundary Mountain and Gander terranes marked by the 
a.

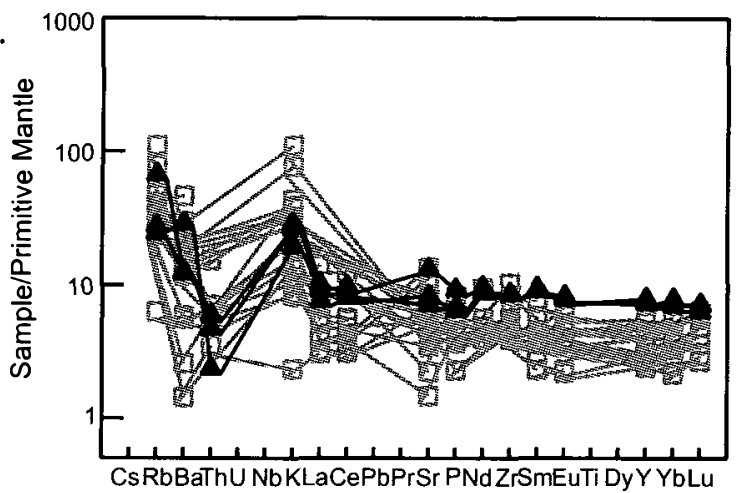

c.

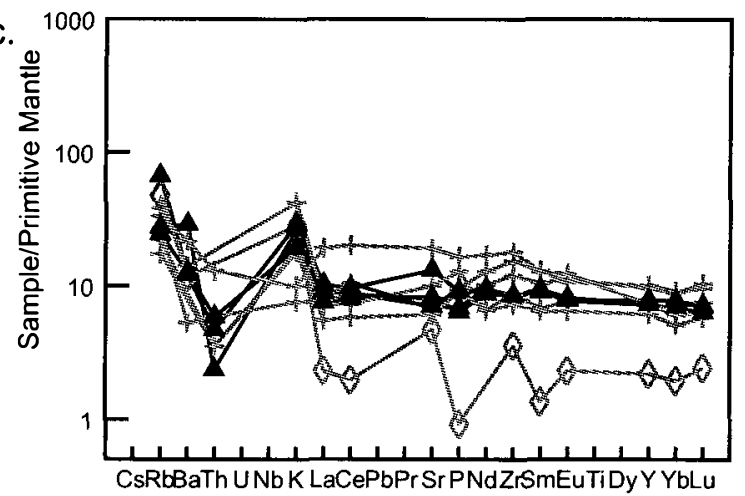

e.
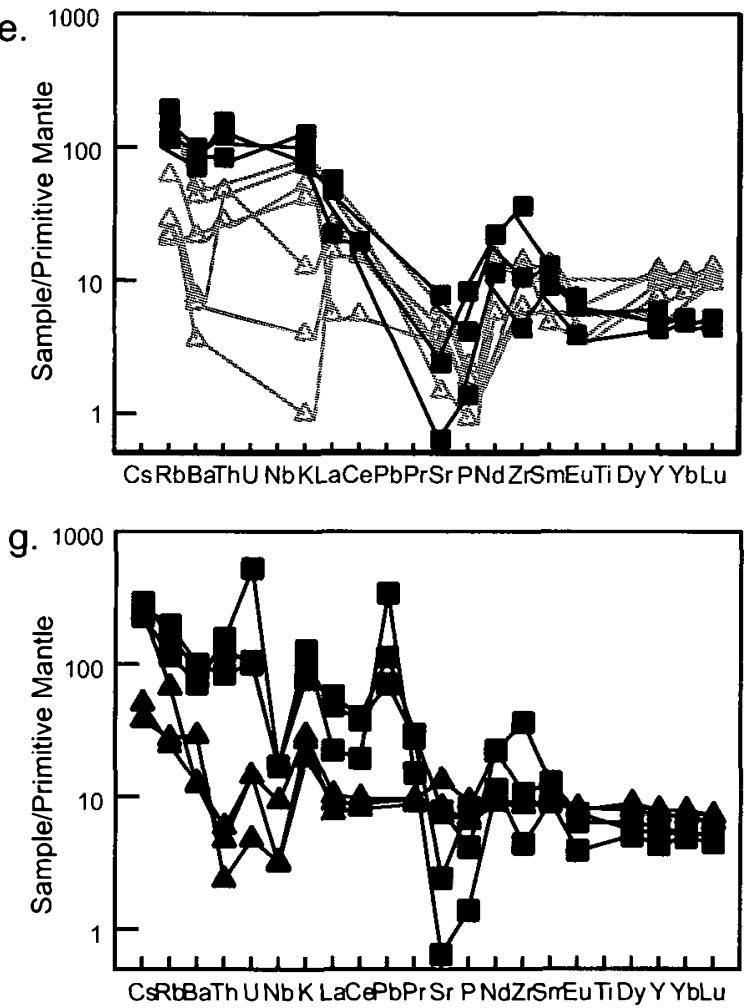
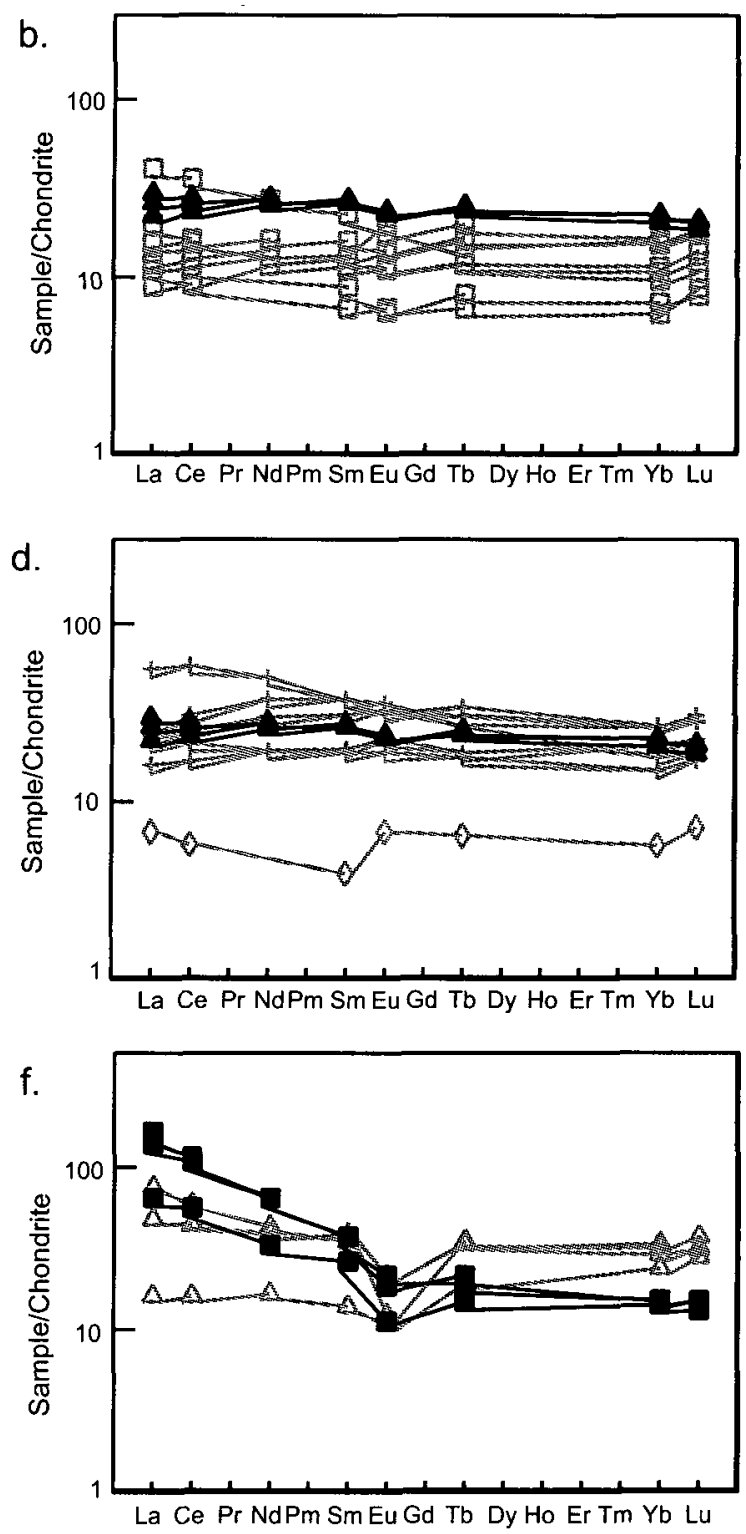

$\Delta$ HM mafic samples $(114,158,163)$

HM felsic samples $(116,147,162)$

+ BM upper mafic unit

$\square$ BM lower mafic unit

$\diamond \mathrm{BM}$ gabbro unit

$\triangle B M$ felsic volcanic unit

(All BM data from Coish and Rogers, 1987)

Fig. 7. Spider diagrams normalized against primitive mantle abundances (Sun and McDonough 1989), and rare earth element diagrams normalized against chondrite abundances (Sun and McDonough 1989). Nb is omitted from (a) $-(\mathrm{f})$ in order to compare with data of Coish and Rogers (1987) for which Nb was not analyzed. Hurricane Mountain mafic and felsic samples with Nb are shown in (g). 


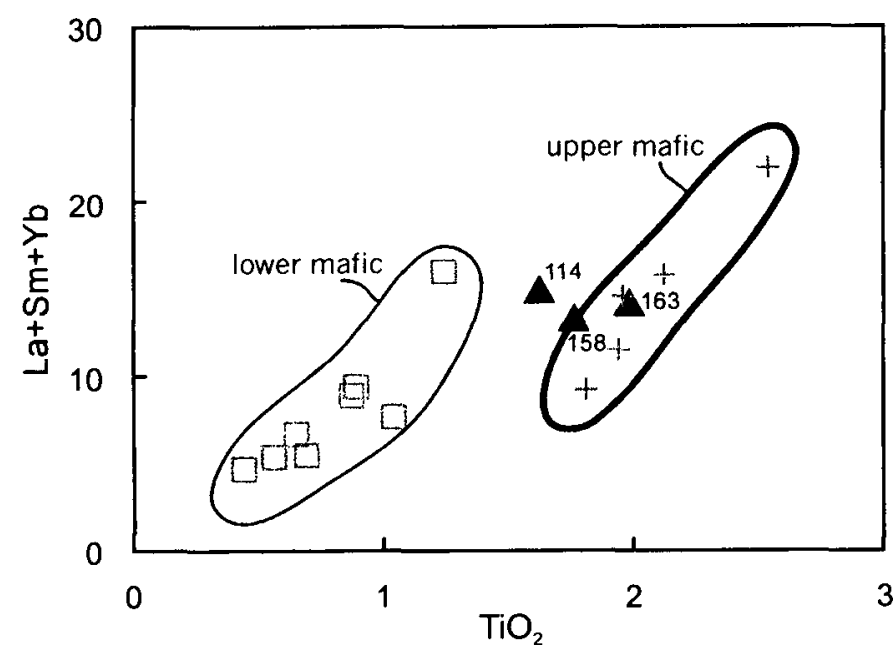

Fig. 8. Plot of $\mathrm{La}+\mathrm{Sm}+\mathrm{Yb}$ vs. $\mathrm{TiO}_{2}$ to distinguish the upper and lower mafic units of the Boil Mountain ophiolite complex. Compositions of the Hurricane Mountain samples are more akin to the upper mafic unit. Symbols are as in Fig. 7.

Fields: $\mathrm{B}=$ Basalt, $\mathrm{T}=$ Trachybasalt, $\mathrm{BTA}=$ Basaltic trachyandesite, $T / B=$ Tephrite $/$ Basanite,$P B=$ Picrobasalt, $B A=$ Basaltic andesite

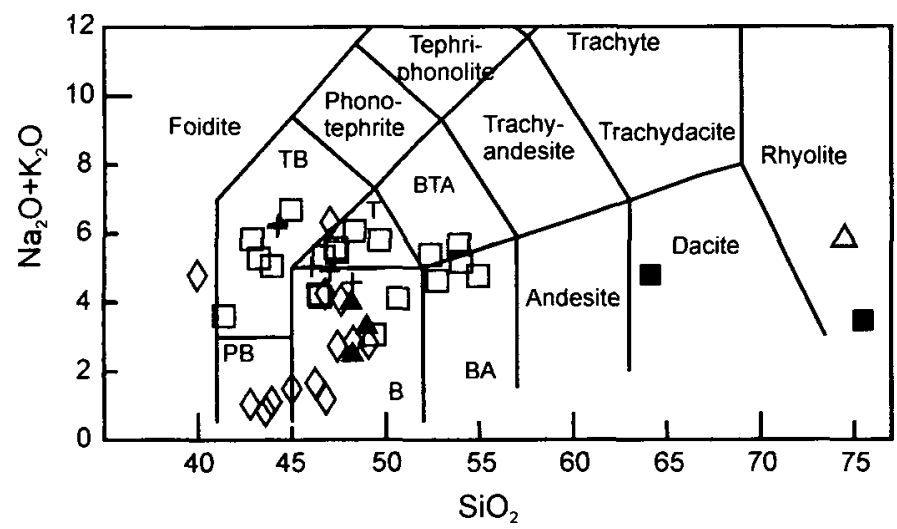

Fig. 9. Classification diagram (fields from Le Bas et al. 1986) shows the range of igneous protoliths for the Hurricane Mountain mafic and felsic blocks, and compares these to the upper mafic, lower mafic, gabbro, and felsic volcanic units of the Boil Mountain ophiolite complex. Symbols are as in Fig. 7.

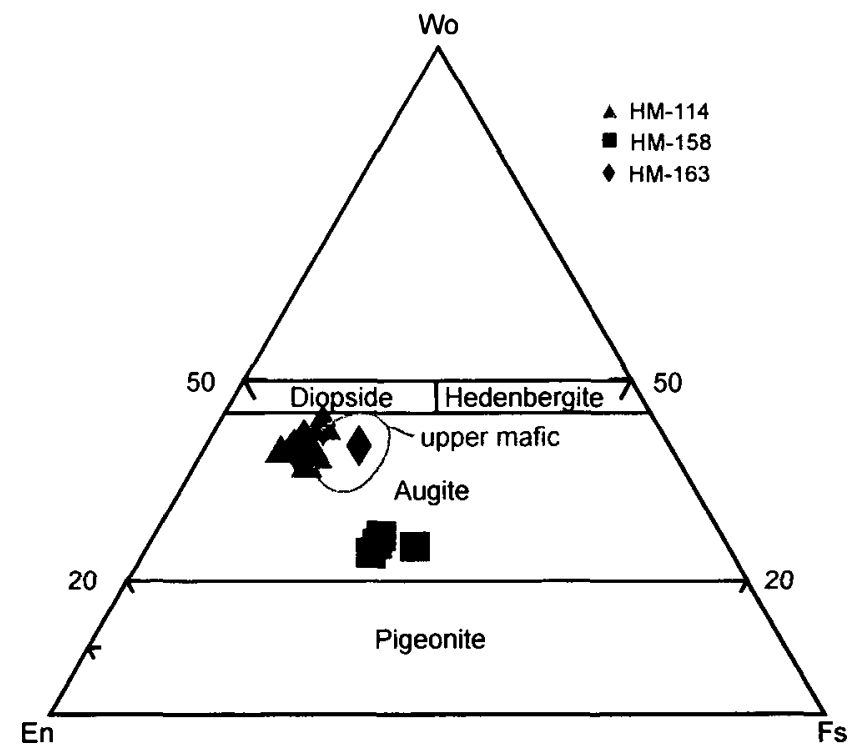

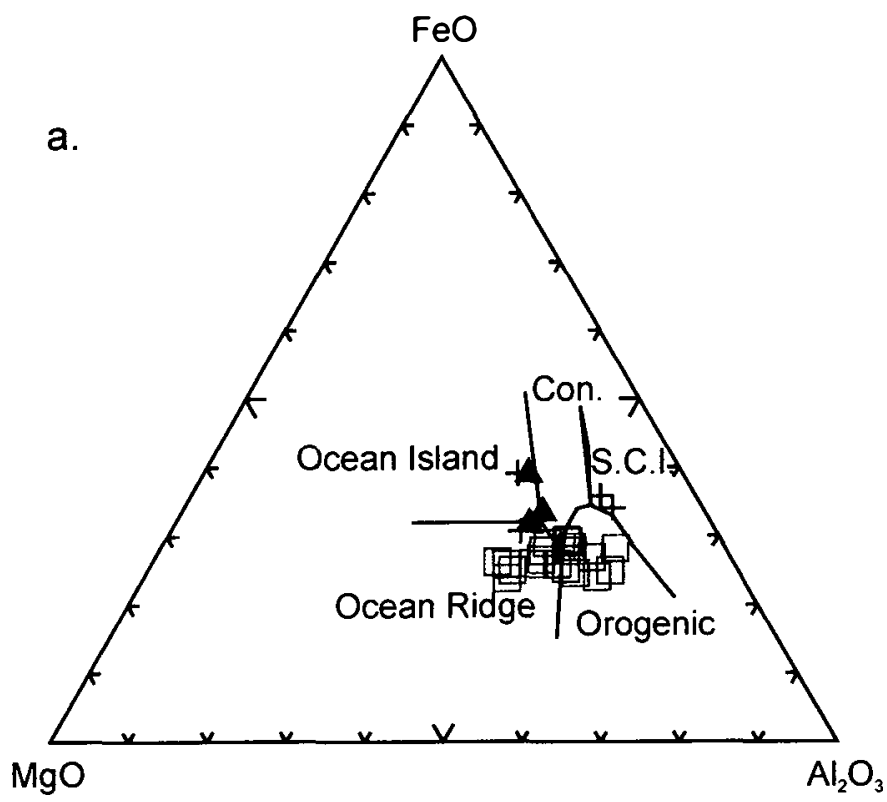

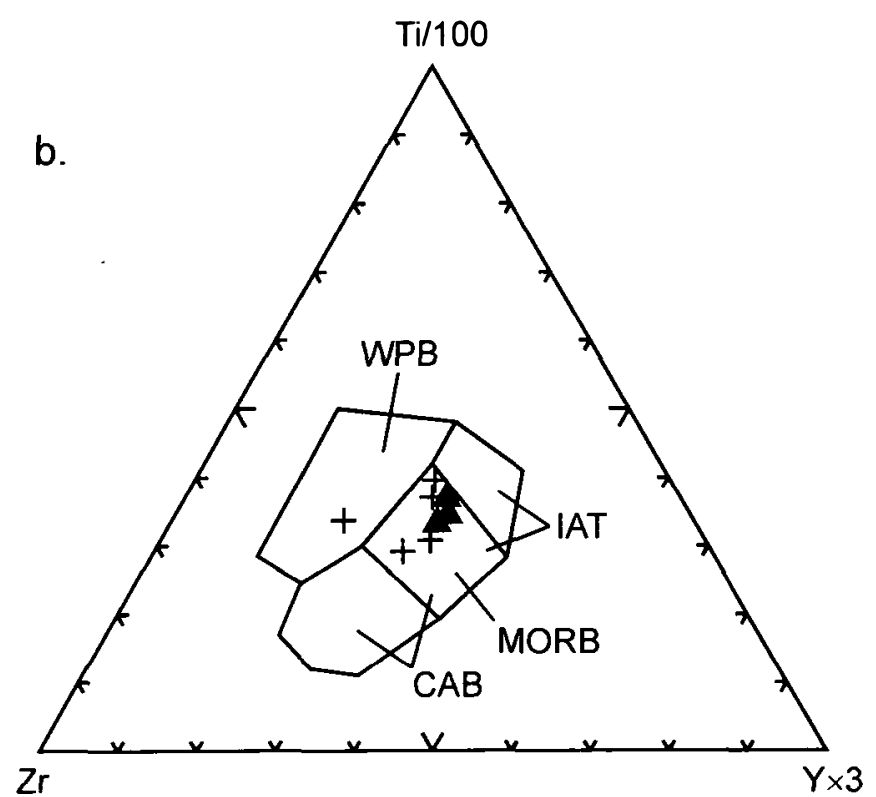

Fig. 10. (a) Major element tectonic diagram according to Pearce et al. (1977). Hurricane Mountain melange samples plot more closely with the upper mafic unit than the lower mafic unit of the Boil Mountain ophiolite complex. (b) Trace element tectonic diagram according to Pearce and Cann (1973). Hurricane Mountain melange samples plot with the Boil Mountain upper mafic unit in the ocean-floor basalt field. WPB $=$ Within plate basalt, IAT = Island arc tholeiite, MORB $=$ Mid-ocean ridge basalt, $\mathrm{CAB}=\mathrm{Calc}$-alkalic basalt. Symbols are as in Fig. 7.

Fig. 11. Clinopyroxene analyses from Hurricane Mountain melange and Boil Mountain ophiolite complex samples plot in the augite field of the clinopyroxene ternary diagram. 
Table 4. Clinopyroxene analyses for samples from the Hurricane Mountain mélange.

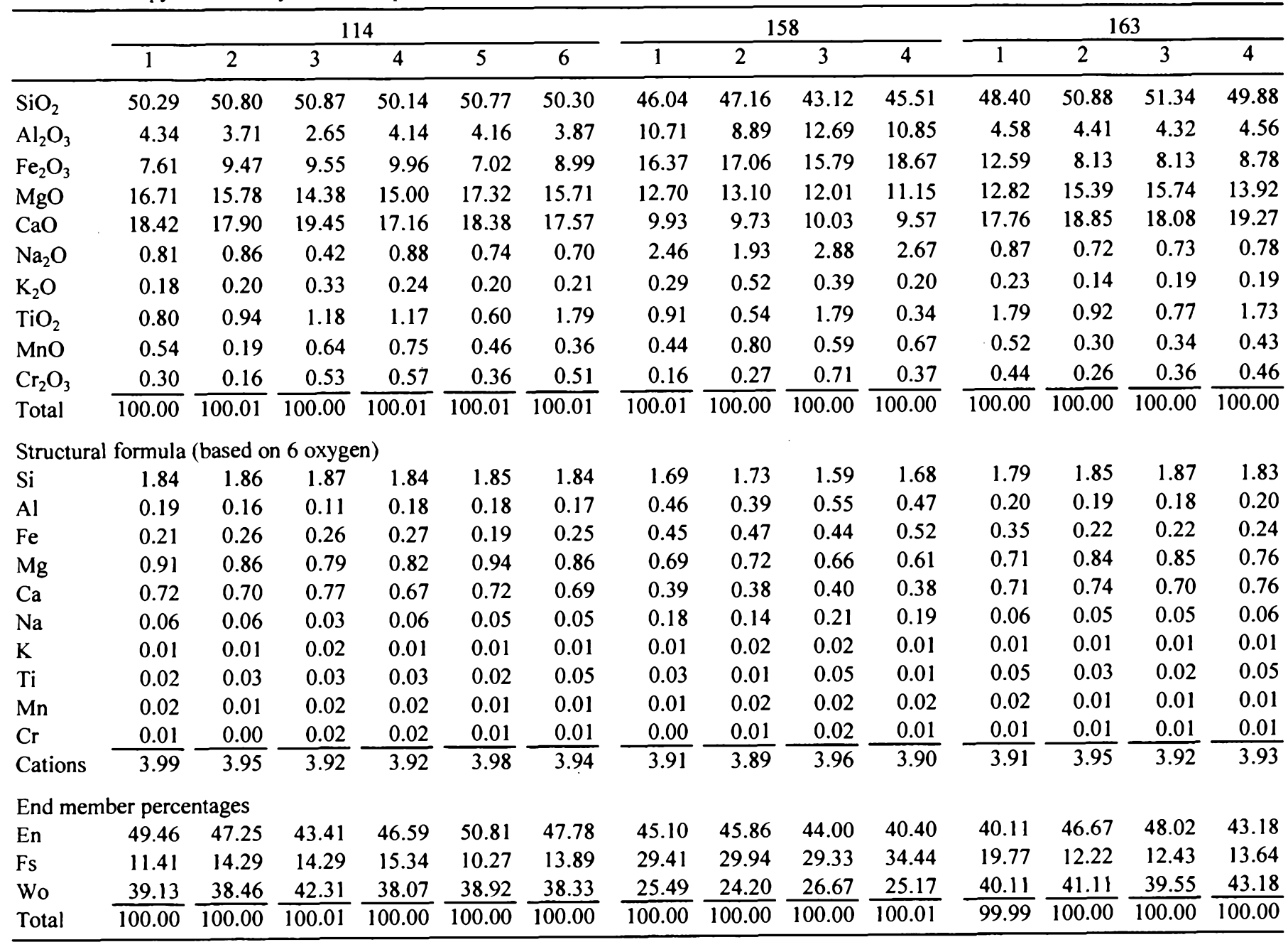
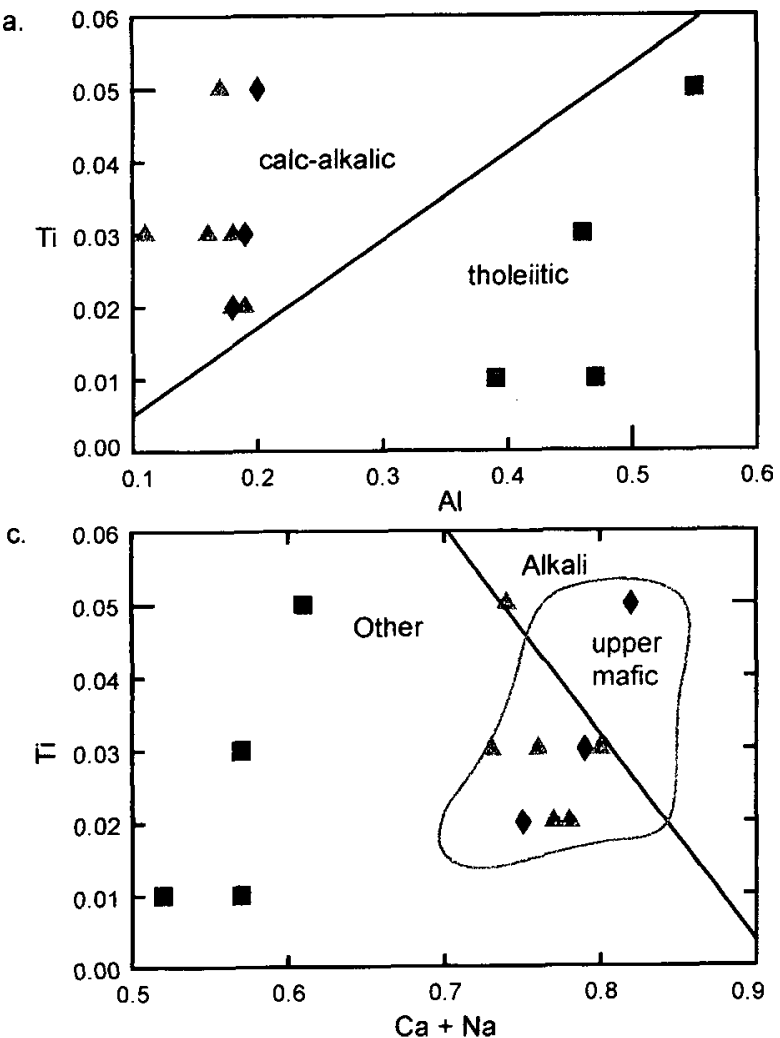

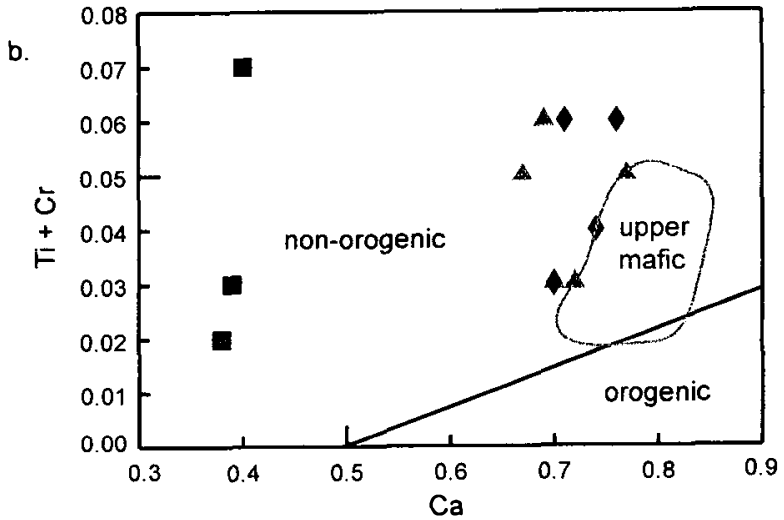

Fig. 12. Clinopyroxene compositions from the Hurricane Mountain and Boil Mountain mafic samples. (a) $\mathrm{Ti}$ vs. Al. (b) $\mathrm{Ti}+\mathrm{Cr}$ vs. Ca (c) Ti vs. $\mathrm{Ca}+\mathrm{Na}$. Upper mafic fields drawn from Coish and Rogers (1987). Divisions are according to Leterrier et al. (1982). Symbols are as in Fig. 11 
Hurricane Mountain mélange (Boone and Boudette 1989) to include the Chase Brook mélange (Pollock 1987). The suspected Boundary Mountain terrane is bounded on the northwest and southeast by ophiolite-mélange-flysch sequences, the St. Daniel mélange belt and the Hurricane Mountain belt, respectively (Boone and Boudette 1989). The Hurricane Mountain sequence marks the Penobscottian suturing of the Boundary Mountain and Gander terranes forming a composite terrane, whereas the St. Daniel sequence formed during the Taconic suturing of the composite Boundary Mountain-Gander terrane to the Laurentian craton (Boone and Boudette 1989). The overlap of areas described as the Boundary Mountain and Dunnage terranes also has led to labelling the St. Daniel belt, in Québec and New Brunswick, as the boundary of the Piedmont and Dunnage terranes (Pollock 1989, Williams and Hatcher 1982).

The St. Daniel mélange belt includes the Thetford Mines ophiolite and the Frontière flysch formation. Like the Dead River Formation, the Frontière flysch formation is interpreted to have originated in the lower part of a fore-arc sequence (Boone and Boudette 1989). Continued comparison between units of ophiolite-mélange-flysch sequences marking terrane boundaries, such as the Boil Mountain ophiolite - Hurricane Mountain mélange - Dead River flysch sequence and the Thetford Mines ophiolite - St. Daniel mélange - Frontière flysch sequence, will augment our understanding of terrane accretion and accretionary mélange formation in the northern Appalachian orogen.

\section{ACKNOWLEDGEMENTS}

Funding for this research has been provided by a Surdna research fellowship to $\mathrm{H}$.V. and a Druckenmiller research fellowship to R.B., both fellowships administered by Bowdoin College. NSF-DUE 99-51390 supported the mineral analyses by SEM. Any opinions, findings, or conclusions expressed in this article are those of the authors and do not necessarily reflect the view of the NSF. We thank G. Boone, $R$. Marvinney, and D. Thomas for enlightening field discussions. We also think R. Cram and J. Lockwood for assistance with the mineral analyses. This manuscript has been improved by helpful reviews by $\mathrm{R}$. Coish and R. Marvinney.

\section{REFERENCES}

ALEINIKOFF, J.N., \& MOENCH, R.H. 1985. Metavolcanic stratigraphy in northern New England - U-Pb zircon geochronology. Geologic Society of America, 17, p. 1.

BOONE, G.M., \& BOUDETTE, EUGENE L. 1989. Accretion of the Boundary Mountains terrane within the northern Appalachian orthotectonic zone. In Geologic Society of America, Special Paper 228, pp. 17-42.

BOONE, G.M., Doty, D.T., \& HEIZLER, M.T. 1989. Hurricane Mountain Formation Mélange: Description and Tectonic Significance of a Penobscottian Accretionary Complex, Maine Geological Survey, Studies in Maine Geology, 2, pp. 33-83.

BOUDETTE, E.L 1982. Ophiolite assemblage of early Paleozoic age in central western Maine. In Major structural zones and faults of the northern Appalachians, Edited by P. St. Julien and J. Beland.
Geological Association of Canada, Special Paper 24, 209-230 $\mathrm{pp}$.

BoudetTe, E.L., Boone, G.M., \& Goldsmith, R. 1985. The PreCambrian Chain Lakes Massif and an Adjacent Cambrian to Lower Ordovician Ophiolite- Mélange-Flysch Succession, In Metamorphism and tectonics of eastern and central North America; Volume 2, Northern Appalachian Transect; southeastern Québec, Canada through western Maine, U.S.A., pp. 28-38.

BURROUGHS, W.A. 1979. Structure of the Dead River Formation in the Forks Quadrangle, West-Central Maine. Unpublished M.Sc. thesis, Syracuse University, $126 \mathrm{p}$.

CoISH, R.A. \& Rogers, N.W. 1987. Geochemistry of the Boil Mountain ophiolitic complex, northwest Maine, and Tectonic Implications, Contributions to Mineralogy and Petrology, 97, pp. $51-65$.

HARKER, A. 1909. The Natural History of lgneous Rocks. Methuen, England. In Rollinson, Hugh. 1993. Using Geochemical Data: Evaluation, Presentation, Interpretation. Longman UK Limited. Essex, England.

Kelemen, P.B., Shimizu, Nobumichi, \& DunN, T. 1993. Relative depletion of niobium in some arc magmas and the continental crust; partitioning of $\mathrm{K}, \mathrm{Nb}$, $\mathrm{La}$ and $\mathrm{Ce}$ during melt/rock reaction in the upper mantle. Earth and Planetary Science Letters, 120, pp. 11-133.

Le Bas, M.J., Le Maitre, R.W., Streckeisen, A., \& Zanettin, B.A. 1986. Chemical classification of volcanic rocks based on the total alkali-silica diagram. Journal of Petrology, 27, pp. 745750.

Leterrier, J., Maury, R.C., Thonon, P., Girard, D., \& MarChal, M. 1982. Clinopyroxene composition as a method of identification of the magmatic affinities of paleo-volcanic series. Earth and Planetary Science Letters, 59, pp. 139-154.

MENZIES, M.A., BlANCHARD, D. XENOPHONTOS, C. 1980. Genesis of the Smartville arc-ophiolite, Sierra Nevada foothills, California. American Journal of Science, 280-A, pp. 329-344.

PEARCE, J.A., \& CANN, J.R. 1973. Tectonic setting of basic volcanic rocks determined using trace element analyses. Earth and Planetary Science Letters, 19, pp. 290-300.

PEARCE, T.H., GORMAN, B.E., \& BIRKETT, T.C. 1977. The relationship between major element chemistry and tectonic environment of basic and intermediate volcanic rocks. Earth and Planetary Science Letters, 36, pp. 121-132.

POLLOCK, S.G. 1989. Melanges and olistostromes associated with ophiolitic metabasalts and their significance in CambroOrdovician forearc accretion in the Northern Appalachians. In Melanges and olistostromes of the U. S. Appalachians, Edited by J.W. Horton and N. Rast. Geological Society of America, Special Paper 228, pp. 43-64.

RAST, N., \& HORTON, J.W. 1989. Melanges and olistostromes in the Appalachians of the United States and mainland Canada; an assessment. In Melanges and olistostromes of the U. S. Appalachians, Edited by J.W. Horton and N. Rast. Geological Society of America, Special Paper 228, pp. 1-15.

SUN, S.S. \& MCDONOUGH, W.F. 1989. Chemical and isotopic systematics of oceanic basalts; implications for mantle composition and processes. Geological Society Special Publications, 42, pp. 313-345.

ThOMAS, D. 2000. Deformation of the Hurricane Mountain Formation Mélange along Tomhegan and Cold Stream, West-Central Maine. Unpublished Senior Project, Bowdoin College, Brunswick, Maine. X p.

VAN StaAL, C. 1991. Dunnage Zone-Gander Zone Relationships in the Canadian Appalachians, Geological Society of America, Abstracts with Programs, 23, p. 143. 
Williams, H. \& HatcheR, R.D., JR. 1982. Suspect Terranes and Accretionary History of the Appalachian Orogen. Geology 10, pp. 530-536.
WILSON, M. 1989. Igneous Petrogenesis: A Global Tectonic Approach. Unwin Hyman Ltd., London, England, 466 pp.

Editorial responsibility: Sandra M. Barr 